\title{
AN IMPACT OF TRAINING ON KNOWLEDGE LEVEL OF PARTICIPANTS
}

\section{OF FARMER'S PRODUCER COMPANIES}

\author{
BALAMOHAN, T. $\mathbf{N}^{1}$, R. VELUSAMY ${ }^{2}$, S. D. SIVAKUMAR ${ }^{3}$ \& M. PRAGADEESWARAN ${ }^{4}$ \\ ${ }^{1}$ Professor and Head, Department of Horticulture, Agricultural College and Research Institute
}

Tamil Nadu Agricultural University, Madurai, Tamil Nadu, India

${ }^{2}$ Associate Professor (Agricultural Extension) Department of Agricultural Extension \& Rural Sociology,

Madurai, Tamil Nadu, India

${ }^{3}$ Director (Agricultural Business Development) TNAU, Coimbatore, Tamil Nadu, India

${ }^{4}$ Assistant Professor (Agricultural Economics), Department of Agricultural Economics, Madurai, Tamil Nadu, India

\begin{abstract}
The Indian market environment changed over the years and leads to difficulties for small farmers in selling their produce. In Tamil Nadu the number of farmer's producer companies is increasing every year. Assessing their knowledge level in their mandate crops and providing training based on their level of knowledge is very important. Keeping this in view the study was conducted to assess the impact of training in their knowledge level. The training was given to sixty one members of Farmer's Producer Organizations in vegetable cultivation and FPO activities. The knowledge level in vegetable cultivation and FPO related activities were measured before and after the training and impact was measured in terms of knowledge gain due to training. Results revealed that one fifth of FPO participants had gained knowledge in the recommended vegetable cultivation techniques. Regarding vegetable cultivation through precision farming nearly half of the participants had gained knowledge about vegetable cultivation through precision farming in the entire category of completely known, somewhat known and little information. Regarding knowledge and management of records 27.87 per cent of participants did not know before training and gained knowledge on these aspects.

KEYWORDS: FPO \& Knowledge Level and Training
\end{abstract}

Received: Apr 27, 2019; Accepted: May 17, 2019; Published: Jun 26, 2019; Paper Id.: IJASRAUG201919

\section{INTRODUCTION}

The farmer producer company is basically a body corporate registered under the Companies Act, 1956 and shall carry on or relate to activities of production, harvesting, processing, procurement, grading, handling, marketing, selling, export of primary produce of the members or import of goods or services for their benefit. Besides, rendering technical services, consultancy services, training, education, research and development and all other activities for the promotion of the interests of its members, generation, transmission and distribution of power, revitalization of land and water resources, their use, conservation and communications relatable to primary produce and promoting mutual assistance, welfare measures, financial services, insurance of producers or their primary produce. The year 2014 was observed as the year of farmer producer organisations (FPO) by the government of India. 
The Indian market environment changed over the years and leads to difficulties for small farmers in selling their produce. Along with changing consumer demands, new corporate actors are entering Indian agro food networks, such as corporate retailers, processors, or exporters of quality produce. These firms are often aiming to execute vertical coordination in their supply chains, which ensures them greater control over the production processes and thus to source produce which meets their strict requirements and standards (Barghouti et al, 2004). Within the frame of vertical coordination, links between farmers and buyers are becoming tighter to replace conventional open-market relations (Humphrey and Memedovic, 2006). This type of procurement organization is also the result of the changing national policy orientation in India, following somewhat neo-liberal tendencies, which is also affecting agriculture and trade (Landes, 2008; Pitale, 2007).

With the amendment of the Companies Act 1956 in 2002, the Indian government introduced the concept of 'producer companies', which constitute an attempt to establish basic business principles within farming communities, to bring industry and agriculture closer together, and to boost rural development (Kumar Sharma, 2008). Producer companies aim to integrate smallholders into modern supply networks to minimizing transaction and coordination costs, while benefiting from economies of scale (Lanting, 2005).

In Tamil Nadu more than 300 farmer's producer companies have emerged for various commodities in a fast manner. Farmer's producer companies are being registered in agricultural and horticultural crops. Both Central and State government are supporting financially and technically for establishing farmer's producer company. It is important to train the members of Farmers Producers Company in their mandate crops and market oriented activities to perform their business and effective functioning of farmer's producer companies. Assessing their knowledge level in their mandate crops and providing training based on their level of knowledge is very important. Keeping this in view, the study was conducted to assess the impact of training in their knowledge level.

\section{RESEARCH METHODOLOGY}

The training on Vegetable cultivation was given to 61 members of farmer's Producer Company from thirty seven FPOs on 25.09.2018 at Agricultural College and Research Institute, Madurai. Interview schedule was constructed in the techniques of vegetable cultivation and FPO related activities in consultation with vegetable scientist, extension functionaries and expert in Farmers producer's organizations. The knowledge level in vegetable cultivation and FPO related activities were measured before conducting training. At the end of the training, the knowledge level of the participants was measured in vegetable cultivation and FPO related activities and impact was measured in terms of knowledge gain due to training.

\section{RESULTS AND DISCUSSIONS}

The knowledge on vegetable cultivation and FPO activities were measured before conduct of training by wellstructured interview schedule and also at the end of training and the results are presented in Table 1.

It could be concluded from the table 1 that one fifth of FPO participants had gained knowledge in recommended vegetable cultivation techniques. Ten per cent of participants did not know anything about vegetable cultivation before attending the training and they gained knowledge about the recommended vegetable cultivation techniques. 
Also 28.00 per cent participants had gained knowledge on vegetable marketing - supply chain techniques. They also gained knowledge on market related information, rates in different markets and value added for vegetable in different stages of marketing.

About vegetable cultivation through precision farming, 42.62 per cent of the participants had gained knowledge about vegetable cultivation through precision farming in all the category of completely known, somewhat known and little information. A meagre percentage of participants $(6.56 \%)$ had not gained knowledge about vegetable cultivation through precision farming even after the training.

Nearly one third of (31.14 per cent) had gained complete knowledge about vegetable cultivation through green house. Nearly one fifth of the participants $(18.04 \%)$ had not known about greenhouse technology before training and gained complete knowledge through this training.

One tenth of $(9.84 \%)$ the participants did not know about pandal vegetable cultivation techniques before training and gained complete knowledge about pandal vegetable cultivation techniques after the training. Nearly one third of participants $(31.15 \%)$ had gained complete knowledge about pandal vegetable cultivation techniques.

Nearly one fourth $(24.69 \%)$ of respondents had gained complete knowledge about hill vegetable cultivation techniques. Considerable portion of respondents $(22.95 \%)$ did not gain the hill vegetable cultivation techniques even after attending the training. This showed the farmers did not show any interest in learning crops which were not common to them.

Regarding the knowledge on opportunities for vegetable export and regulations, 27.87 percentages of participants had gained knowledge at the end of the training. Nearly one fifth of farmers (19.67\%) did not gain any information related to vegetable export and regulations even after attending the training.

\section{Knowledge Gained in FPO Activities}

The knowledge level in FPO related activates were measured before training and knowledge gained also measured at the end of the training and the results are presented in the table 2 .

Half of the respondents $(47.54 \%)$ had gained the knowledge on FPC starting and processing procedure. Nearly one fourth of $(22.95 \%)$ participants did not know about the FPC starting and processing procedure before the training. At the end of the training, all the participants did agree about the procedures for starting FPC starting and processing procedure.

Majority of the respondents had gained knowledge about the business plan and future business plan. Considerable changes were observed in the category from very little information to complete information.

Also it is observed from the table that only a meagre percentage (4.92 \$) of participants had knowledge about GST for FPO before training and nearly two fifth of respondents had gained knowledge on GST after the training.

Regarding knowledge and management of records 27.87 per cent of participants did not know before training and gained knowledge on these aspects. Nearly half (44.27 per cent) of the respondents had little information before training and gained complete information regarding the maintenance of records. 


\section{CONCLUSIONS}

The study concludes that participants from Farmer's producer organizations had gained knowledge in recent technologies in production, value addition, value chain of products, maintenance of records, business plan and GST related information. Participants did not learn the information in the area of non-interested subject like hill vegetable cultivation, formation of FPO.

\section{REFERENCES}

1. Barghouti S, Kane S, Sorby K, Ali M, 2004, "Agricultural diversification for the poor: guidelines for practitioners", Agriculture and Ru ral Development discussion paper, World Bank, Washington, DC

2. Humphrey J, Memedovic O, 2006, "Global value chains in the agri food sector", working paper, United Nations Industrial Development Organization, Vienna

3. Kumar Sharma G, 2008, "Producer companies: facilitating producers to do business in a better way", http://www.irma.ac.in/others/network past issue. php?network issue id=84

4. Landes M, 2008, 'The environment for agricultural and agribusiness investment in India",

5. Lanting H, 2005, “Building a farmer-own ed company and linking it to international fashion houses under fair-trade arrangements", paper presented at the International Conference on Engaging Communities, $14 \wedge 17$ August, Brisbane, Queensland, http://www.engagingcommunities200 5.org/abstracts/S21-lanting-h.html

6. Pitale R L, 2007 India: $R$ ich Agricultu re Poor Farmers (Daya Publishing House, New Delhi)

7. Meenakshi, V., \& Pirabu, J. V. (2015). A scale to measure the attitude of rice farmers towards indigenous traditional knowledge practices. International Journal of Agricultural Science and Research (IJASR), 5(4), 167-172.

\section{APPENDIES}

Table 1: Knowledge on Vegetable Cultivation before and after Training $(n=61)$

\begin{tabular}{|c|c|c|c|c|c|c|c|c|c|c|c|c|c|c|c|c|c|}
\hline \multirow{3}{*}{ S.No } & \multirow{3}{*}{ Particulars } & \multicolumn{8}{|c|}{ Before Training } & \multicolumn{8}{|c|}{ After Training } \\
\hline & & \multicolumn{2}{|c|}{$\begin{array}{c}\text { Completely } \\
\text { known }\end{array}$} & \multicolumn{2}{|c|}{$\begin{array}{l}\text { Somewhat } \\
\text { Known }\end{array}$} & \multicolumn{2}{|c|}{$\begin{array}{c}\text { Little } \\
\text { Information }\end{array}$} & \multicolumn{2}{|c|}{ Not Known } & \multicolumn{2}{|c|}{$\begin{array}{l}\text { Completely } \\
\text { Known }\end{array}$} & \multicolumn{2}{|c|}{$\begin{array}{c}\text { Somewhat } \\
\text { Known }\end{array}$} & \multicolumn{2}{|c|}{$\begin{array}{c}\text { Little } \\
\text { Informatio } \\
n\end{array}$} & \multicolumn{2}{|c|}{ Not Known } \\
\hline & & No & $\begin{array}{c}\text { Per } \\
\text { Cent }\end{array}$ & No & $\begin{array}{c}\text { Per } \\
\text { Cent }\end{array}$ & No & $\begin{array}{c}\text { Per } \\
\text { Cent }\end{array}$ & No & $\begin{array}{l}\text { Per } \\
\text { Cent }\end{array}$ & No & $\begin{array}{c}\text { Per } \\
\text { Cent }\end{array}$ & No & $\begin{array}{l}\text { PER } \\
\text { Cent }\end{array}$ & No & $\begin{array}{l}\text { PER } \\
\text { Cent }\end{array}$ & No & $\begin{array}{l}\text { Per } \\
\text { Cent }\end{array}$ \\
\hline 1 & $\begin{array}{l}\text { Vegetable } \\
\text { cultivation } \\
\text { techniques }\end{array}$ & 14 & 22.95 & 33 & 54.10 & 8 & 13.11 & 6 & 9.84 & 29 & 47.54 & 30 & 49.18 & 1 & 1.64 & 1 & 1.64 \\
\hline 2 & $\begin{array}{l}\text { Vegetable } \\
\text { marketing -supply } \\
\text { chain techniques }\end{array}$ & 7 & 11.48 & 32 & 52.46 & 13 & 21.31 & 9 & 14.75 & 24 & 39.34 & 32 & 52.46 & 2 & 3.28 & 3 & 4.92 \\
\hline 3 & $\begin{array}{l}\text { Vegetable } \\
\text { cultivation using } \\
\text { precision farming }\end{array}$ & 13 & 21.31 & 22 & 36.07 & 22 & 36.07 & 4 & 6.56 & 26 & 42.62 & 20 & 32.79 & 11 & 18.03 & 4 & 6.56 \\
\hline 4 & $\begin{array}{l}\text { Vegetable } \\
\text { cultivation using } \\
\text { greenhouse } \\
\text { technology }\end{array}$ & 6 & 9.84 & 27 & 44.26 & 9 & 14.75 & 19 & 31.15 & 25 & 40.98 & 18 & 29.51 & 10 & 16.39 & 8 & 13.11 \\
\hline 4 & $\begin{array}{l}\text { Pandal vegetable } \\
\text { cultivation } \\
\text { techniques }\end{array}$ & 12 & 19.67 & 28 & 45.90 & 9 & 14.75 & 12 & 19.67 & 31 & 50.82 & 21 & 34.43 & 3 & 4.92 & 6 & 9.84 \\
\hline 5 & $\begin{array}{l}\text { Hill vegetable } \\
\text { cultivation } \\
\text { techniques }\end{array}$ & 4 & 6.56 & 13 & 21.31 & 17 & 27.87 & 27 & 44.26 & 19 & 31.15 & 19 & 31.15 & 9 & 14.75 & 14 & 22.95 \\
\hline 6 & $\begin{array}{l}\text { Opportunities for } \\
\text { vegetable export } \\
\text { and import export } \\
\text { rules and } \\
\text { regulations }\end{array}$ & 2 & 3.28 & 17 & 27.87 & 22 & 36.07 & 20 & 32.79 & 19 & 31.15 & 22 & 36.07 & 8 & 13.11 & 12 & 19.67 \\
\hline
\end{tabular}


Table 2: Knowledge on FPO Activities before and after Training $(\mathrm{n}=61)$

\begin{tabular}{|c|l|c|c|c|c|c|c|c|c|}
\hline S.No & Questions & \multicolumn{5}{|c|}{ Before Training } & \multicolumn{4}{c|}{ After Training } \\
\hline & $\begin{array}{c}\text { Completely } \\
\text { Known }\end{array}$ & $\begin{array}{c}\text { Somewhat } \\
\text { Known }\end{array}$ & $\begin{array}{c}\text { Little } \\
\text { Information }\end{array}$ & $\begin{array}{c}\text { Not } \\
\text { Known }\end{array}$ & $\begin{array}{c}\text { Completely } \\
\text { Known }\end{array}$ & $\begin{array}{c}\text { Somewhat } \\
\text { Known }\end{array}$ & $\begin{array}{c}\text { Little } \\
\text { Information }\end{array}$ & $\begin{array}{c}\text { Not } \\
\text { Known }\end{array}$ \\
\hline 1 & $\begin{array}{l}\text { FPC starting } \\
\text { and processing } \\
\text { procedure }\end{array}$ & $10(16.39)$ & $23(37.70)$ & $14(22.95)$ & $14(22.95)$ & $39(63.93)$ & $22(36.77)$ & $0(0.00)$ & $0(0.00)$ \\
\hline 2 & $\begin{array}{l}\text { FPOs business } \\
\text { plan }\end{array}$ & $22(36.06)$ & $28(45.90)$ & $8(13.11)$ & $3(4.91)$ & $29(47.54)$ & $26(42.62)$ & $2(3.27)$ & $3(4.91)$ \\
\hline 3 & $\begin{array}{l}\text { Future } \\
\text { businessplan }\end{array}$ & $20(32.78)$ & $28(45.90)$ & $10(16.39)$ & $3(4.91)$ & $28(45.90)$ & $26(42.62)$ & $3(4.91)$ & $4(6.55)$ \\
\hline 4 & $\begin{array}{l}\text { CEO\& BODs } \\
\text { functions \& } \\
\text { liabilities }\end{array}$ & $12(19.67)$ & $16(26.63)$ & $16(26.23)$ & $10(27.87)$ & $34(55.74)$ & $23(37.70)$ & $4(6.56)$ & $0(0.00)$ \\
\hline 5 & $\begin{array}{l}\text { knowledge and } \\
\text { management } \\
\text { of records }\end{array}$ & $9(14.75)$ & $24(39.34)$ & $11(18.03)$ & $17(27.87)$ & $36(59.02)$ & $22(36.07)$ & $3(4.92)$ & $0(0.00)$ \\
\hline 6 & $\begin{array}{l}\text { Awareness of } \\
\text { document } \\
\text { required for } \\
\text { ROC }\end{array}$ & $9(14.75)$ & $21(34.43)$ & $15(24.59)$ & $16(26.23)$ & $36(59.02)$ & $20(32.79)$ & $5(8.20)$ & $0(0.00)$ \\
\hline 7 & $\begin{array}{l}\text { Impact of GST } \\
\text { inFPC }\end{array}$ & $3(4.92)$ & $14(22.95)$ & $19(31.15)$ & $25(40.98)$ & $27(44.26)$ & $19(31.15)$ & $12(19.67)$ & $3(4.92)$ \\
\hline
\end{tabular}


